Article

\title{
Void Formation/Elimination and Viscoelastic Response of Polyphenylsilsesquioxane Monolith
}

\author{
Yusuke Daiko ${ }^{D}$, Yuki Oda, Sawao Honda and Yuji Iwamoto * (iD \\ Department of Life Science and Applied Chemistry, Nagoya Institute of Technology, Gokiso-cho, Showa-ku, \\ Nagoya, Aichi 466-8555, Japan; daiko.yusuke@nitech.ac.jp (Y.D.); 28411042@stn.nitech.ac.jp (Y.O.); \\ honda@nitech.ac.jp (S.H.) \\ * Correspondence: iwamoto.yuji@nitech.ac.jp
}

Received: 18 April 2018; Accepted: 15 May 2018; Published: 19 May 2018

\begin{abstract}
Polyphenylsilsesquioxane $\left(\mathrm{PhSiO}_{3 / 2}\right)$ particles as an organic-inorganic hybrid were prepared using sol-gel method, and monolithic samples were obtained via a warm-pressing. The reaction mechanism of particles' polymerization and transformation to the monolith under the warm-press were investigated using solid state ${ }^{29} \mathrm{Si}$ nuclear magnetic resonance (NMR) spectrometer, thermal gravimetric-differential thermal analyzer (TG-DTA), mass spectrometer (MS) and scanning electron microscope (SEM). Transparent and void-free monoliths are successfully obtained by warm-pressing above $180^{\circ} \mathrm{C}$. Both the terminal $-\mathrm{OH}$ groups on particles' surface and warm-pressing are necessary for preparation of void-free $\mathrm{PhSiO}_{3 / 2}$ monolith. From the load-displacement measurement at various temperatures, a viscoelastic deformation is seen for $\mathrm{PhSiO}_{3 / 2}$ monolith with voids. On the other hand, an elastic deformation is seen for void-free $\mathrm{PhSiO}_{3 / 2}$ monolith, and the void-free monolith shows much higher breakdown voltage.
\end{abstract}

Keywords: silsesquioxane; power module; void; viscoelasticity; breakdown voltage

\section{Introduction}

An organic-inorganic hybrid of polyphenylsilsesquioxane (PPSQ, $\mathrm{PhSiO}_{3 / 2}$ ) has attracted much attention owing to its unique thermal softening and curing properties since Brown et al. reported the $\mathrm{PhSiO}_{3 / 2}$ as a ladder polymer with a stereoregular double chain structure in 1960 [1-6]. Various applications for a passivation layer for the InGaZnO transistor [6,7], hybridization with epoxy resin [8], beauty care [9], a rhodamine 6G-doped laser [10], framework of cage crystals [11,12] and gemini surfactant [13], have also been reported so far. $\mathrm{PhSiO}_{3 / 2}$ particle with monodispersed size was successfully prepared using a two-step acid-base catalyzed sol-gel process, and its size, molecular weight and glass transition temperature vary by controlling the sol-gel conditions such as the amount of added ethanol solvent and concentration/amount of acid-base catalysis [14,15]. One big advantage of $\mathrm{PhSiO}_{3 / 2}$ particle is that a monolithic bulk can be obtained by pressing the particles. For example, press-formed monolithic bulk electrolytes have been reported so far [16-18]. In the case for synthesis of a thick film with thickness $>1 \mu \mathrm{m}$, crack generation is inevitable using conventional dip- or spin-coating sol-gel techniques, and thus repetitive dry/sintering and coating cycles are generally required. Kozuka succeeded in obtaining a crack free thick film without the repetitive coatings by utilizing a polyvinylpyrrolidone (PVP) assisted sol-gel method [19-21]. On the other hand, $\mathrm{PhSiO}_{3 / 2}$ particles possess a negative zeta potential $(\sim-30 \mathrm{mV})$ and those particles are deposited on conductive substrates via an electrophoretic deposition method, and thick films with arbitrary thickness and high transparency are obtained after a heat treatment [22,23].

We have investigated an application of $\mathrm{PhSiO}_{3 / 2}$ particles for an insulating layer of a power semiconductor. Ceramics with high thermal conductivity, such as $\mathrm{AlN}$ and $\mathrm{Si}_{3} \mathrm{~N}_{4}$, have been used for 
the insulating layer [24,25]. Due to their susceptibility to crack generation during prolonged operation and their high fabrication cost, composite insulating layers consisting with epoxy resin and ceramic filler (e.g., boron nitride) for increasing thermal conductivity have also been developed so far [26]. From the strong demand of both the higher efficiency and energy saving of the power semiconductor, material shift from conventional silicon $(\mathrm{Si})$ to silicon carbide $(\mathrm{SiC})$ was gradually seen since the late 1980 's [27,28]. SiC-based power devices have various advantages including high frequency operation, high thermal conductivity, high breakdown voltage and high-temperature operating capability higher than $200{ }^{\circ} \mathrm{C}$ owing to its wide bandgap compared with silicon [29,30]. High temperature operation leads to decrease the volume of heat sink (cooling system). From the view point of increasing the operation temperature, we anticipated that $\mathrm{PhSiO}_{3 / 2}$ will be a candidate for the insulating layer instead of epoxy resin due to its high thermal stability.

For the insulating layer, void, which is one typical manufacturing-induced defect, adversely affects both the thermal conductivity and insulation property [31-33]. Also, voids can cause crack generation and crack growth $[34,35]$. Finite element computations for the correlation between voids and crack growth have been extensively studied [34,36]. Adriaensens et al. propose an nuclear magnetic resonance (NMR) imaging technique for detecting the number of voids in isobutylene-based elastomers [37]. The work presented here is aimed at in-situ monitoring void formation/elimination through the warm-pressing of $\mathrm{PhSiO}_{3 / 2}$ particles in order to prevent as possible the negative effects of voids. In this paper, we report the mechanism of $\mathrm{PhSiO}_{3 / 2}$ polymerization via warm-pressing and its relation with void formation/elimination. A hysteresis behavior between loading and unloading of the load-displacement measurement (viscoelastic to elastic transition) was found to be well correlated with the number of induced voids. We also found an enhancement of the alternating current (AC) breakdown voltage for the elastic-response samples.

\section{Materials and Methods}

Materials Phenyltriethoxysilane (PhTES) (98\%) was purchased from Aldrich (St. Louis, MO, USA) and used as received without further purification. For hydrolysis reaction, PhTES ( $5 \mathrm{~mL})$ was added drop by drop to ethanol (EtOH) and hydrochloric acid (0.01 mass \%) mixture at room temperature, and the solution was stirred for $90 \mathrm{~min}$. The solution was then added quickly to ammonia water $(0.28$ mass \%) for reaction of dehydration condensation, and further stirred for $90 \mathrm{~min}$. The molar ratio of PhTES:EtOH: $\mathrm{H}_{2} \mathrm{O}$ (in $\mathrm{HCl}$ solution): $\mathrm{H}_{2} \mathrm{O}$ (in $\mathrm{NH}_{4} \mathrm{OH}$ solution) was 1:10:40:120. The resultant $\mathrm{PhSiO}_{3 / 2}$ particles were washed by repeated dispersion in $\mathrm{H}_{2} \mathrm{O}$ and centrifugation and then dried at $60{ }^{\circ} \mathrm{C}$ [14-16]. Monolithic (pelletized) bulk sample was prepared by pressing the $\mathrm{PhSiO}_{3 / 2}$ particles at $120 \mathrm{MPa}$ for $15 \mathrm{~min}$ using a metal mold $\left(10 \mathrm{~mm}\right.$ in diameter) at $25^{\circ} \mathrm{C}$, followed by increasing temperature to $120 \sim 280^{\circ} \mathrm{C}$ and further pressed at $120 \mathrm{MPa}$ for $15 \mathrm{~min}$.

The morphology of samples was observed using a scanning electron microscope (JEOL, JSM-6010LA, Tokyo, Japan). A thermal gravimetric-differential thermal analyzer (TG-DTA) (Rigaku, TG8120, Tokyo, Japan) was used to measure the weight loss and glass transition temperature at a heating rate of $10{ }^{\circ} \mathrm{C} / \mathrm{min}$. The mass of gases from $\mathrm{PhSiO}_{3 / 2}$ was also studied by TG/DTA (Hitachi High Technologies Ltd., STA7200, Tokyo, Japan) and simultaneous mass spectrometry (JEOL, JMS-Q1500 GC, Tokyo, Japan) under flowing helium $(100 \mathrm{~mL} / \mathrm{min})$ as a carrier gas with a heating rate of $10{ }^{\circ} \mathrm{C} / \mathrm{min}$. Solid state ${ }^{29} \mathrm{Si}$ magic-angle spinning nuclear magnetic resonance (MAS NMR, Varian, Inc., Palo Alto, CA, USA) measurement was carried out using a Varian Unity 400 plus spectrometer. The NMR spectra were measured at $79.45 \mathrm{MHz}, 6 \mu \mathrm{s}$ of $90^{\circ}$ pulse length, $30 \mathrm{~s}$ of decay time between pulses, and MAS spinning rate of $3.5 \mathrm{kHz}$.

The load-displacement curves under both loading and unloading was measured using a testing machine (Instron 5582, Instron Japan company Ltd., Kanagawa, Japan). $\mathrm{PhSiO}_{3 / 2}$ particles were preliminary pressed at $5 \mathrm{kN}$ and $25^{\circ} \mathrm{C}$ using the aforementioned metal mold (10 mm in diameter), and then load-displacement curves were measured at $25,120,140,160$ and $180^{\circ} \mathrm{C}$. The load was increased up to $8 \mathrm{kN}$ with cross-head speed of $0.005 \mathrm{~mm} / \mathrm{s}$, and then decreased to $0 \mathrm{~N}$ with the same 
speed. The loading-unloading cycle was repeated twice. A small electric furnace was used to control the temperature as shown in Figure 1. The alternate current (AC) breakdown voltage for $\mathrm{PhSiO}_{3 / 2}$ monolith was measured at $60 \mathrm{~Hz}$ using a dielectric strength tester (Tsuruga Electric Corporation, Model 8504, Osaka, Japan) at $25^{\circ} \mathrm{C}$ and the measurement was performed inside Fluorinert (FC-40, 3M Japan Ltd., Tokyo, Japan) liquid in order to prevent an electric discharge of air. Silver paste electrodes (Dotite D-362, Fujikura Kasei Co., Ltd., Tokyo, Japan) were used. Five samples were prepared for each measurement. The voltage was increased stepwise $(0.1 \mathrm{kV} /$ step and $3 \mathrm{~s}$ of the interval time for each step). The voltage at the current over $0.5 \mathrm{~mA}$ was detected as a breakdown voltage.

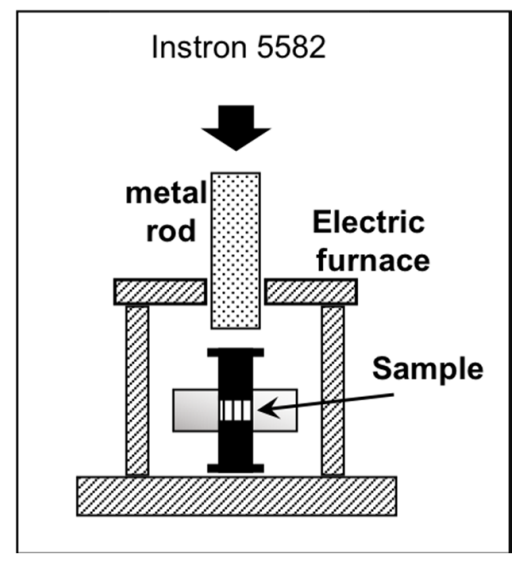

Figure 1. Schematic diagram of the setup for temperature-controlled load-displacement measurement using an Instron.

\section{Results and discussion}

\subsection{Structure and Degree of $\mathrm{PhSiO}_{3 / 2}$ Polymerization via Warm-Pressing}

The obtained $\mathrm{PhSiO}_{3 / 2}$ particles were approximately 1-2 $\mu \mathrm{m}$ in diameter. Monolith sample after pressing at $25^{\circ} \mathrm{C}$ was opaque white, whereas that warm-pressing at $180{ }^{\circ} \mathrm{C}$ was transparent as shown in Figure 2a,c. However, many small bubbles were seen inside the monolith prepared at $180{ }^{\circ} \mathrm{C}$. Cross sectional SEM images for both samples are also shown in Figure 2b,d. Although $\mathrm{PhSiO}_{3 / 2}$ particles are deformed under pressing at $25^{\circ} \mathrm{C}$, particles' interfaces and voids between particles are clearly observed. On the other hand, such interfaces and voids decreased clearly for the monolith sample prepared at $180^{\circ} \mathrm{C}$.
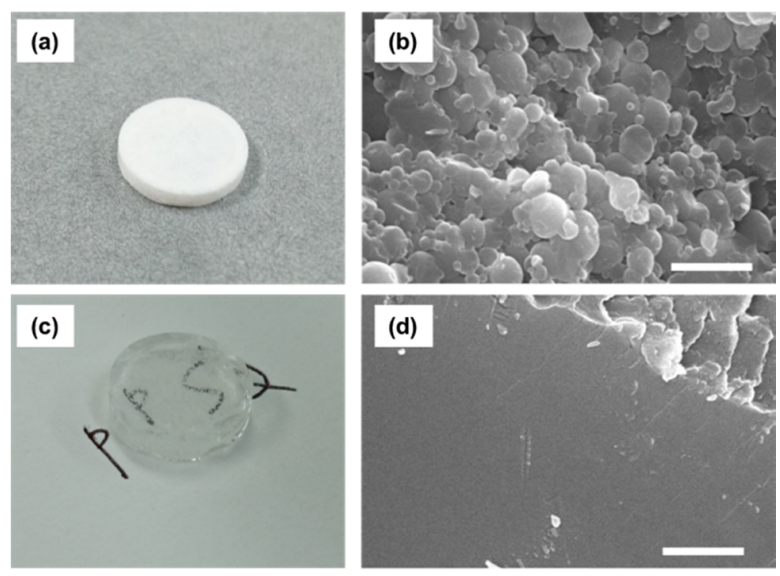

Figure 2. Photos and cross-sectional SEM images of monolithic samples prepared at $25{ }^{\circ} \mathrm{C}(\mathbf{a}, \mathbf{b})$, and at $180^{\circ} \mathrm{C}(\mathbf{c}, \mathbf{d})$, respectively. Bars in SEM images indicate $5 \mu \mathrm{m}$. 
${ }^{29} \mathrm{Si}$ NMR spectra for samples prepared at various temperature (warm-pressing) are shown in Figure 3. Two peaks are observed at $-73 \mathrm{ppm}$ and $-82 \mathrm{ppm}$, which are assigned to $\mathrm{T}^{2}$ and $\mathrm{T}^{3}$ units, respectively (the $n$ in $\mathrm{T}^{n}$ indicates the number of bridging oxygen). In general, sol-gel-derived non-bridging oxygen in the $\mathrm{T}^{2}$ unit exists as terminal hydroxyl $(-\mathrm{OH})$ or unreacted ethoxy $\left(-\mathrm{OC}_{2} \mathrm{H}_{5}\right)$ groups. The peak intensity for the $\mathrm{T}^{3}$ unit increases with increasing the press temperature, suggesting the polymerization of $\mathrm{PhSiO}_{3 / 2}$ particles under the warm-pressing.

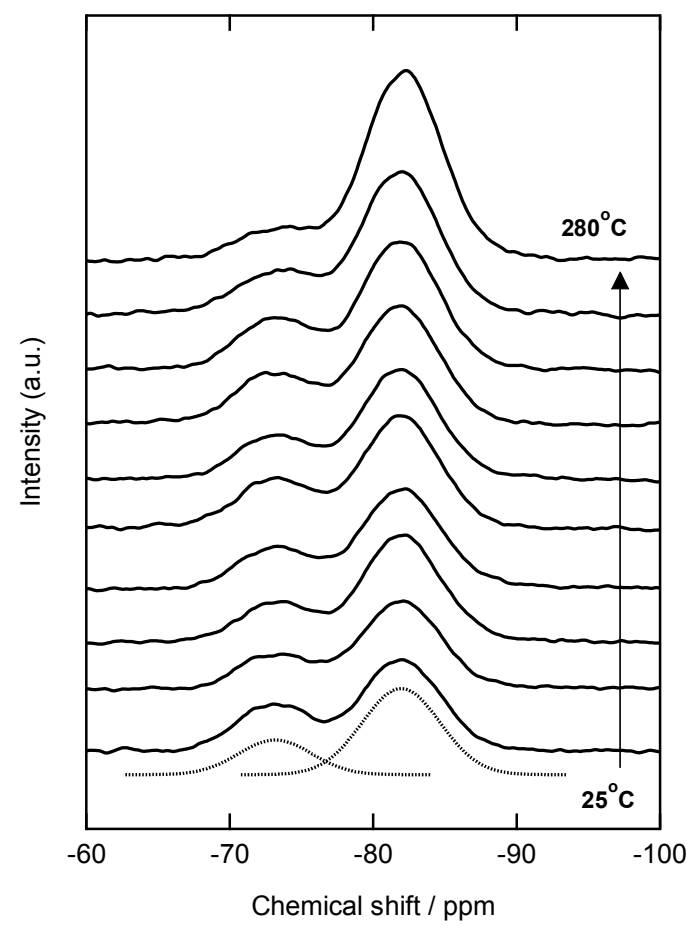

Figure 3. ${ }^{29} \mathrm{Si}$ NMR spectra for samples prepared via warm-pressing at 25, 140, 150, 160, 170, 180, 190, 200,250 and $280{ }^{\circ} \mathrm{C}$. Dotted lines at $25^{\circ} \mathrm{C}$ are a result of peak deconvolution.

Takahashi et al. reported that the glass transition temperature ( $\mathrm{Tg}$ ) of $\mathrm{PhSiO}_{3 / 2}$ is in the range from 90 to $130{ }^{\circ} \mathrm{C}$ [15]. Figure 4 shows DTA curve of as-prepared $\mathrm{PhSiO}_{3 / 2}$ particles, and the $\mathrm{Tg}$ is estimated to be $110^{\circ} \mathrm{C}$. It is thus we adopted the temperature of warm-pressing above $110{ }^{\circ} \mathrm{C}$. From the TG curve observed simultaneously with DTA, the weight loss of $\mathrm{PhSiO}_{3 / 2}$ particles up to $280{ }^{\circ} \mathrm{C}$ was calculated to be $1.3 \mathrm{wt} \%$. The gas analysis was also carried out using a mass spectrometer, and results are shown in Figure 5a. Up to $280{ }^{\circ} \mathrm{C}$, gaseous species, the $\mathrm{m} / \mathrm{z}$ ratios of 18 and 17 were observed. These are assigned to $\mathrm{H}_{2} \mathrm{O}$ (a small relative intensity of the $m / z=17$ is a fragment ion of $\mathrm{H}_{2} \mathrm{O}$, which is also an evidence of water evaporation). No other molecules concerning with residual ethoxy groups such as $\mathrm{OC}_{2} \mathrm{H}_{5}, \mathrm{C}_{2} \mathrm{H}_{5}$ and $\mathrm{CO}_{2}$ were detected, suggesting the hydrolysis reaction of ethoxy groups proceeded completely and the aforementioned non-bridging oxygen exists as terminal hydroxyl groups.

Thermal stability was measured at $230{ }^{\circ} \mathrm{C}$ since SiC-based power devices can operate above $200{ }^{\circ} \mathrm{C}$. As shown in Figure $5 \mathrm{~b}$, during a heat treatment at $230{ }^{\circ} \mathrm{C}$ for $24 \mathrm{~h}$, a slight weight changes less than $0.1 \mathrm{wt} \%$ was confirmed for the monolith prepared by warm-pressing at $280{ }^{\circ} \mathrm{C}$. The first weight loss from 100 to approximately $99.4 \mathrm{wt} \%$ under the heating is due to the dissociation of absorbed surface water. 

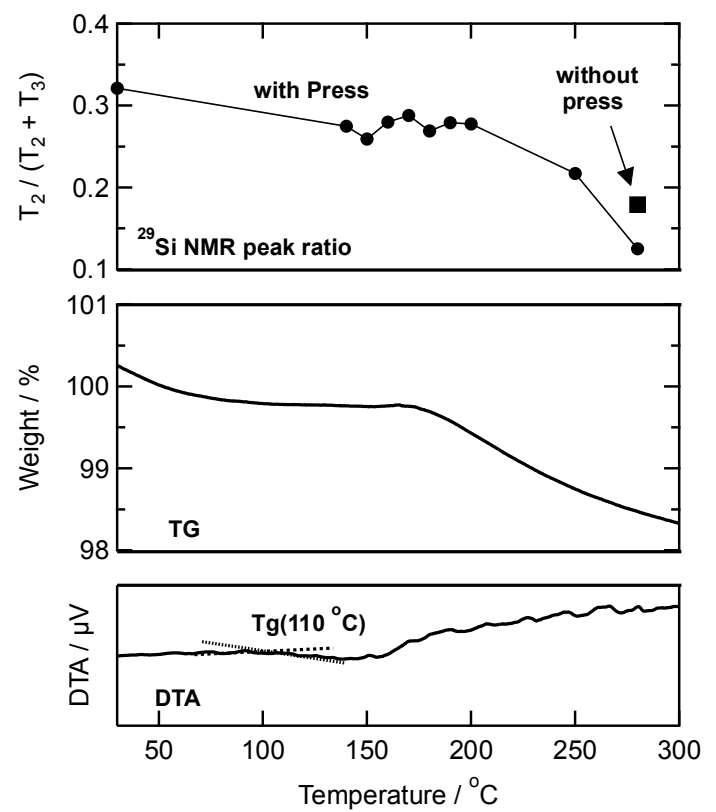

Figure 4. Changes in temperature of DTA and TG curves, and the ratio of $\mathrm{T}^{2}$ units calculated from ${ }^{29} \mathrm{Si}$ NMR peak areas of $\mathrm{T}^{2}$ and $\mathrm{T}^{3}$ for $\mathrm{PhSiO}_{3 / 2}$ monoliths prepared with and without pressing.

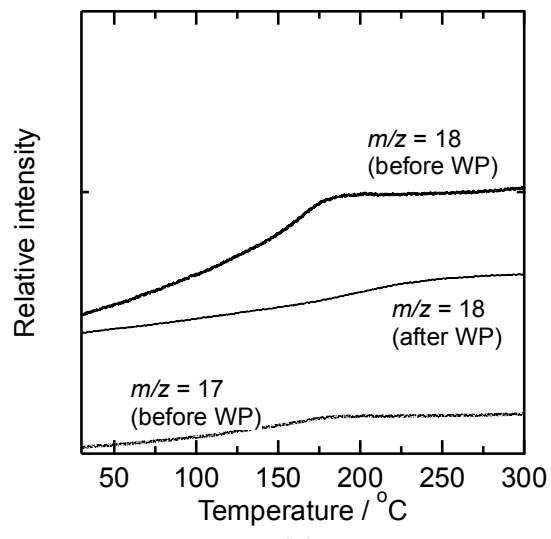

(a)

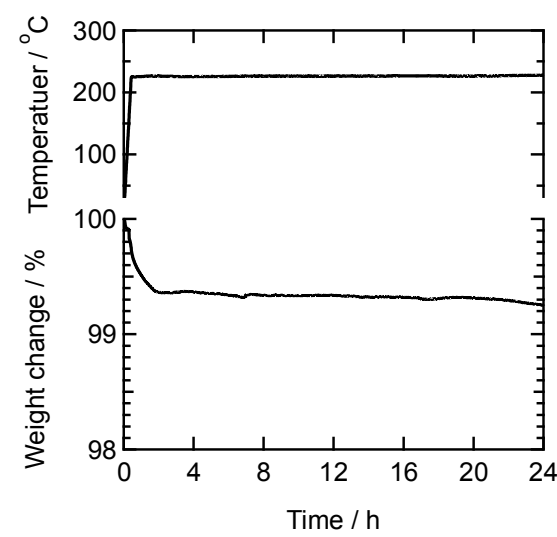

(b)

Figure 5. (a) Constituents of gaseous species for $\mathrm{PhSiO}_{3 / 2}$ particles as a function of temperature, and (b) changes in weight of a $\mathrm{PhSiO}_{3 / 2}$ monolith at $230{ }^{\circ} \mathrm{C}$ prepared by warm-pressing at $280{ }^{\circ} \mathrm{C}$.

The molar ratio of $\mathrm{T}^{2}$ and $\mathrm{T}^{3}$ units was estimated from a peak deconvolution of ${ }^{29} \mathrm{Si} \mathrm{NMR}$ peak area as shown dotted lines in Figure 3 (at $25{ }^{\circ} \mathrm{C}$ as an example), and calculated ratios of $\mathrm{T}^{2}$ for total silsesquioxane $\left(\mathrm{T}^{2}+\mathrm{T}^{3}\right)$ are also shown in Figure 4 together with DTA/TG results. Before the warm-pressing, the ratio of $\mathrm{T}^{2}$ was 0.32 . The molecular weight for each monolith $\left(M_{\text {monolith }}\right)$ prepared at different temperatures was estimated as follows;

$$
\begin{gathered}
f_{T 2}=\frac{A_{T 2}}{A_{T 2}+A_{T 3}}, \quad f_{T 3}=\frac{A_{T 3}}{A_{T 2}+A_{T 3}} \\
M_{\text {monolith }}=f_{T 2} \times M_{T 2}+f_{T 3} \times M_{T 3}
\end{gathered}
$$

where $A_{\mathrm{T} 2}$ and $A_{\mathrm{T} 3}$ are the ${ }^{29} \mathrm{Si}$ NMR peak areas, $f_{\mathrm{T} 2}$ and $f_{\mathrm{T} 3}$ are the molar fractions, and $M_{\mathrm{T} 2}$ $(138.2 \mathrm{~g} / \mathrm{mol})$ and $M_{\mathrm{T} 3}(129.2 \mathrm{~g} / \mathrm{mol})$ are the molecular weights for $\mathrm{T}^{2}$ and $\mathrm{T}^{3}$ units, respectively. For example, for $1 \mathrm{~mol}$ of $\mathrm{PhSiO}_{3 / 2}$ particles, the sample weight for as-prepared $\mathrm{PhSiO}_{3 / 2}$ particle is $0.32 \times 138.2+0.68 \times 129.2=132.07 \mathrm{~g}$, whereas the sample weight after heating at $280{ }^{\circ} \mathrm{C}$ (without 
pressing) is $0.18 \times 138.2+0.72 \times 129.2=130.81 \mathrm{~g}$. Note that the change in the $\mathrm{T}^{2}$ fraction as a function of temperature is in good agreement with the weight loss curve (TG) (Figure 4). Weight loss is estimated to be approximately $1.0 \mathrm{wt} \%$ based on the result of ${ }^{29} \mathrm{Si} \mathrm{NMR}$, which agree well with the result of TG $(1.3 \mathrm{wt} \%)$. Also, the fraction of $\mathrm{T}^{2}$ decreases effectively by pressing $\left(f_{\mathrm{T} 2}=0.12\right)$ as compared with that prepared without pressing $\left(f_{\mathrm{T} 2}=0.18\right)$.

From these results, the reaction of the monolith formation of $\mathrm{PhSiO}_{3 / 2}$ particles under the warm-pressing is progressed as shown in Figure 6. Hydroxyl groups as the non-bridging oxygen of $\mathrm{T}^{2}$ on particle surface react and the dehydration condensation occurs, resulting into the evaporation of $\mathrm{H}_{2} \mathrm{O}$ gas and which cause the formation of bubbles inside the monolith as shown in Figure 2c. These bubbles degrade the insulation property, and a slow increase for approximately a few min up to $120 \mathrm{MPa}$ was effective in order to eliminate bubbles (to remove $\mathrm{H}_{2} \mathrm{O}$ gas). The dehydration condensation reaction promotes effectively by the warm-pressing owing to increase the contact area of $\mathrm{PhSiO}_{3 / 2}$ particles. After the warm-pressing, the amount of evaporated $\mathrm{H}_{2} \mathrm{O}$ decreases significantly. This is also an evidence of the dehydration condensation reaction during the warm-pressing. Both the terminal -OH groups on particles' surface and warm-pressing above the glass transition temperature are necessary for preparation of void-free $\mathrm{PhSiO}_{3 / 2}$ monolith. Since we obtain a void-free $\mathrm{PhSiO}_{3 / 2}$ monolith at $180^{\circ} \mathrm{C}, \mathrm{T}^{2}$ units $(-\mathrm{OH})$ remaining above $180{ }^{\circ} \mathrm{C}$ are considered to be mainly placed inside $\mathrm{PhSiO}_{3 / 2}$ particles which is not removed at temperatures up to $280^{\circ} \mathrm{C}$.

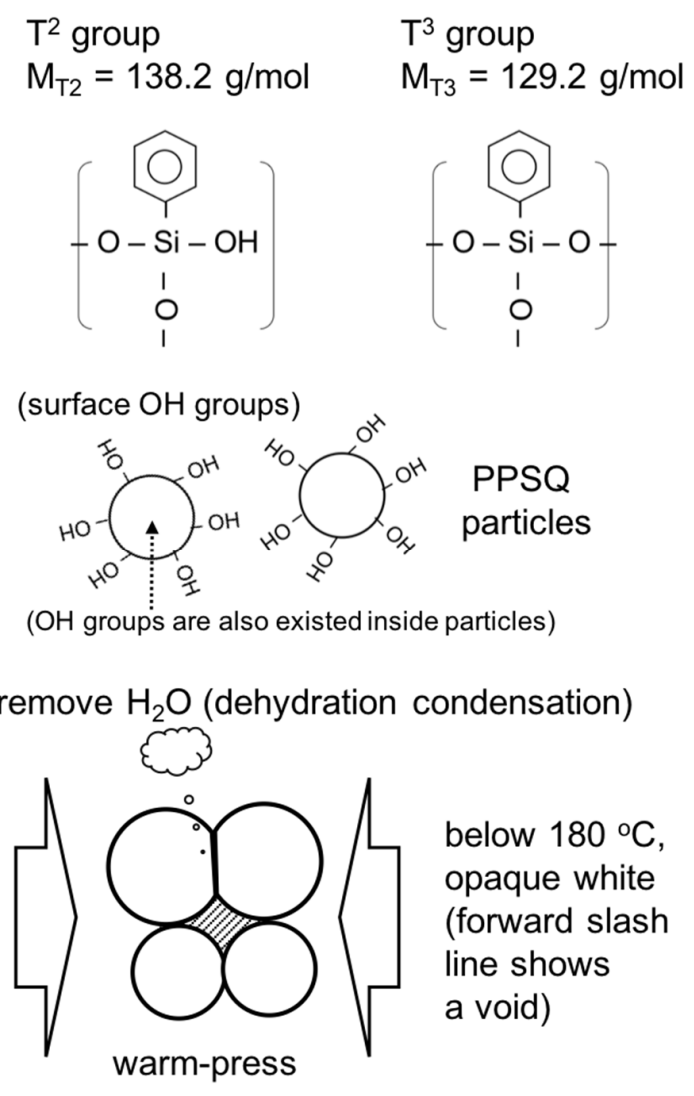

Figure 6. Schematic diagram of dehydration condensation of $\mathrm{PhSiO}_{3 / 2}$ particles.

\subsection{Loading-Unloading Hysteresis and Void Formation}

The deformation of $\mathrm{PhSiO}_{3 / 2}$ particles was confirmed by SEM observation, even at room temperature pressing. However, particles' interfaces and voids are disappeared after warm-pressing above $180^{\circ} \mathrm{C}$. The mechanical response for the structural changes under the reaction of dehydration condensation was measured using an Instron. Figure 7a shows the load-displacement curves measured 
at temperatures ranging from 25 to $180{ }^{\circ} \mathrm{C}$. The displacement for the metal mold and rod are not considered. In the case for the first loading-unloading cycle, a plastic deformation was observed for all temperatures, which is attributed to the deformation of $\mathrm{PhSiO}_{3 / 2}$ particles. The consecutive second loading-unloading cycles at the same temperature are shown in Figure $7 \mathrm{~b}$. The plastic deformation was not observed, and the displacement for unloading recovered to $0 \mathrm{~mm}$ at $0 \mathrm{kN}$. Note that a hysteresis between the loading and unloading is clearly seen except the measurement at $180{ }^{\circ} \mathrm{C}$. This hysteresis is corresponding to a typical viscoelastic deformation. At $180^{\circ} \mathrm{C}$, the unloading curve was completely overlapped with the loading one, suggesting an elastic deformation.
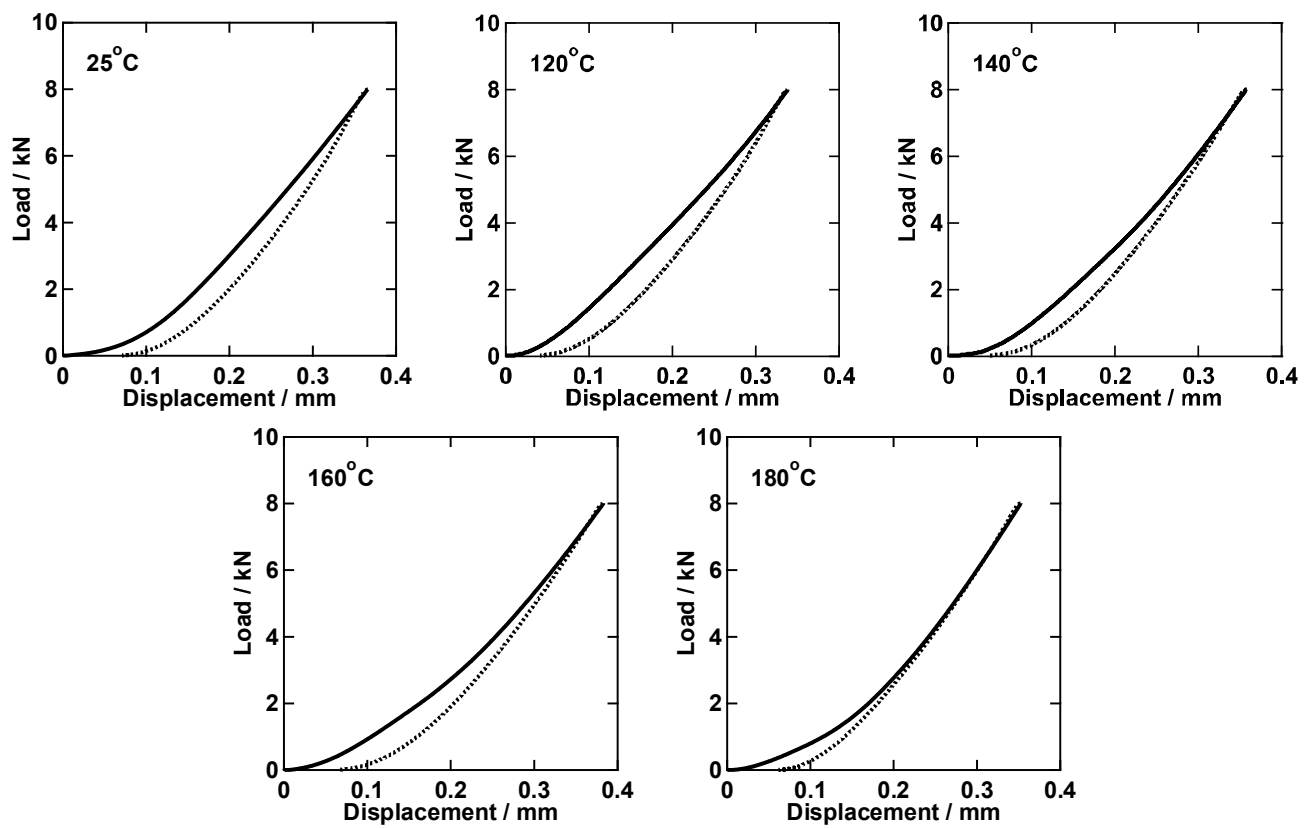

(a)
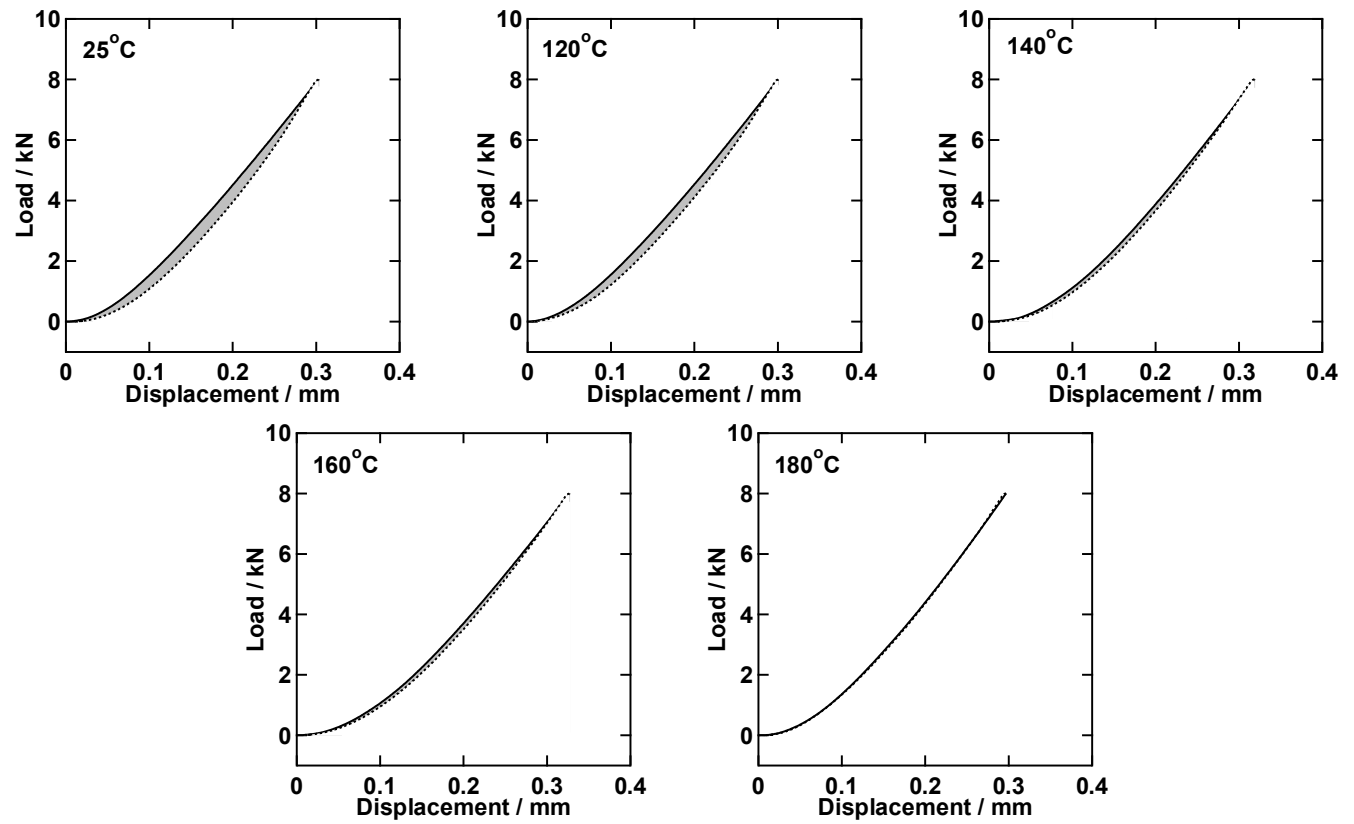

(b)

Figure 7. Load-displacement curves measured at various temperatures (a) the first loading-unloading cycles and (b) consecutive second loading-unloading cycles (solid line: loading, dotted line: unloading). 
Linear viscoelastic models are made up of linear springs and linear viscous dashpots [38]. The linear spring and dashpot elements are expressed as follows.

$$
\begin{gathered}
\sigma=E \cdot \mathcal{E} \quad \text { (spring) } \\
\sigma=\eta \cdot \mathrm{d} \varepsilon / \mathrm{d} t \quad(\text { dashpot) }
\end{gathered}
$$

where $\sigma$ is the stress, $\varepsilon$ is the strain, $E$ is the Young's modulus and $\eta$ is the coefficient of viscosity. At the first loading, a plastic deformation of $\mathrm{PhSiO}_{3 / 2}$ particles occurs and a monolith is obtained. Below $180^{\circ} \mathrm{C}$, samples are partially opaque white because of the unsatisfied dehydration condensation (void formation).

On the other hand, a transparent and void free monolith was obtained at $180^{\circ} \mathrm{C}$, and the second cycle behavior of which can be expressed only by a spring element. These results strongly suggest that the viscoelastic response induced by the dashpot element at the second cycle is correlated strongly with voids between $\mathrm{PhSiO}_{3 / 2}$ particles' interfaces.

The hysteresis area of the second loading-unloading cycle is corresponding to a deformation energy, and the energy for $1 \mathrm{~mol}$ of $\mathrm{PhSiO}_{3 / 2}$ was estimated from the hysteresis area by integration of loading and unloading curves. Figure 8 shows the relationship between the pressing temperature and the deformation energy. Note that the temperature dependence of the energy is also in good agreement with the fraction of $\mathrm{T}^{2}$ units as well as the weight loss shown in Figure 4. As above mentioned about the mechanism of hydration condensation, $-\mathrm{OH}$ groups exist on $\mathrm{PhSiO}_{3 / 2}$ particles' surface, and such surface $-\mathrm{OH}$ groups remaining after the warm-pressing should be observed around voids. We assumed that the number of voids and remaining - $\mathrm{OH}$ groups is correlated directly with each other. As shown in Figure 9, a good linear correlation is successfully obtained between the deformation energy and the fraction of $\mathrm{T}^{2}$ unit (=-OH groups). The viscoelastic deformation energy estimated from the hysteresis of loading-unloading curves is an effective parameter in order to in-situ monitor the formation/elimination of voids during the warm-pressing.

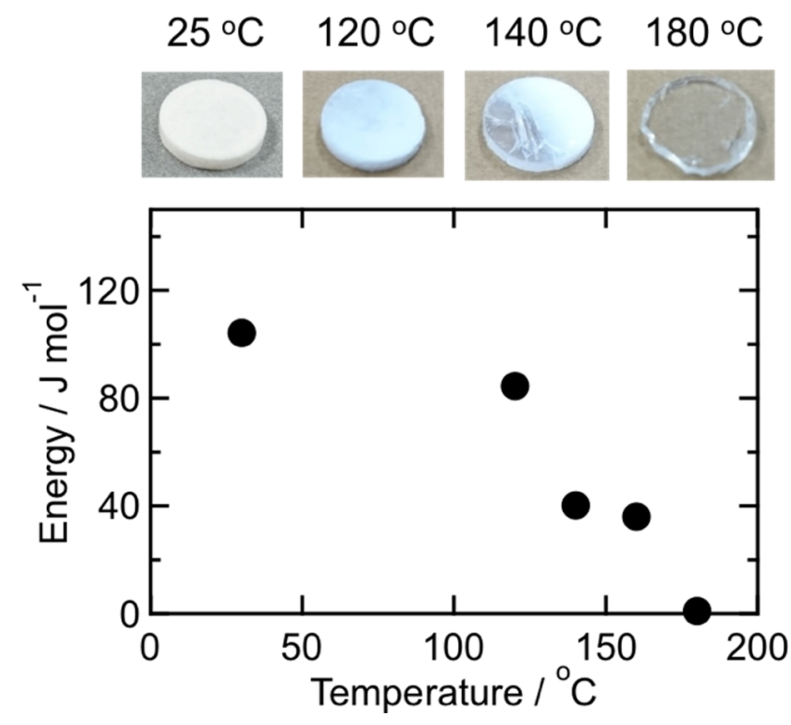

Figure 8. Relationship between the warm-pressing temperature and the deformation energy corresponding to the hysteresis area shown as grey color in Figure 7 (2nd cycle).

Further investigations, including the time dependences and the stress relaxation under the warm-pressing, are in progress. Insulating resins for power modules, ceramic fillers are mixed together to increase the thermal conductivity, and voids are often induced at resin/filler interfaces. We have also investigated about the mechanical response for organosilsesquioxane and ceramic filler composites 
using the aforementioned technique, and a similar hysteresis behavior was confirmed. These results will be reported elsewhere.

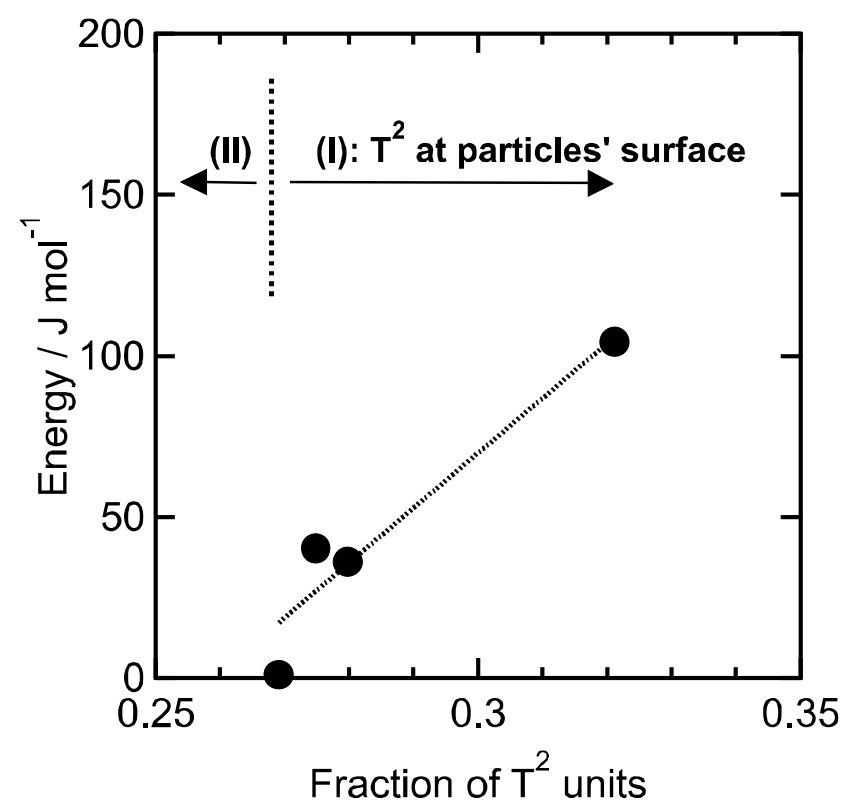

Figure 9. Relationship between the fraction of $\mathrm{T}^{2}$ units and the deformation energy. The fraction above 0.27 (region I) is corresponding to the $-\mathrm{OH}$ groups placed at particles' surface, and below 0.27 (region II) is that placed inside particles.

\subsection{AC Insulating Property}

The breakdown voltage of the $\mathrm{PhSiO}_{3 / 2}$ monolith was measured at $25{ }^{\circ} \mathrm{C}$ in order to clarify the effect of voids on the voltage. $\mathrm{PhSiO}_{3 / 2}$ monoliths warm-pressed at $140{ }^{\circ} \mathrm{C}$ showed the breakdown voltage around $4.8 \mathrm{kV} / \mathrm{mm}$. On the other hand, the voltage improves higher than $15 \mathrm{kV} / \mathrm{mm}$ for all monoliths warm-pressed at $180{ }^{\circ} \mathrm{C}$. The maximum voltage of the dielectric strength tester is $10 \mathrm{kV}$, and we could not estimate the breakdown voltage with high accuracy for $180^{\circ} \mathrm{C}$ samples. The breakdown voltage above $30 \mathrm{kV}$ (0.5 mm thickness) was reported for epoxy resin/alumina composite insulators [39]. As discussed in Figure 8, voids are existing in samples prepared at $140{ }^{\circ} \mathrm{C}$, whereas samples prepared at $180{ }^{\circ} \mathrm{C}$ are void free based on the results of viscoelastic measurement. These voids cause a partial discharge, leading to an electric breakdown [40]. Effective enhancement of the AC breakdown voltage for the elastic-response samples are experimentally confirmed. Mechanical responses using the similar technique for filler and olganosilsesquioxane composites and detailed analysis about the dashpot element will be reported soon.

\section{Conclusions}

Polyphenylsilsesquioxane $\left(\mathrm{PhSiO}_{3 / 2}\right)$ monoliths were prepared using sol-gel-derived $\mathrm{PhSiO}_{3 / 2}$ particles by a warm-pressing, and the condensation reaction, void formation/elimination and insulating property were investigated. The monolith is formed through a dehydration condensation between -OH groups on particles' surface. A deformation of $\mathrm{PhSiO}_{3 / 2}$ particles was seen even at $25^{\circ} \mathrm{C}$ at $120 \mathrm{MPa}$ of the pressure, however the obtained monolith was opaque white and particles' interfaces and voids were clearly observed. A void free monolith was successfully obtained by the warm-pressing of $\mathrm{PhSiO}_{3 / 2}$ particles above $180{ }^{\circ} \mathrm{C}$. The fraction of $-\mathrm{OH}$ groups $\left(\mathrm{T}^{2}\right.$ units) and a deformation energy induced by a dashpot element were estimated from the ${ }^{29} \mathrm{Si}$ NMR and the hysteresis area of loading-unloading curves, respectively. It was found that there is a good linear relationship between them. Compared with the observation of voids utilizing other techniques such as 
SEM or porosity analysis, this hysteresis analysis has a significant benefit since the results about void formation and elimination are obtained simultaneously during $\mathrm{PhSiO}_{3 / 2}$ particles' warm-pressing, and which can be applied for various manufacturing-induced defects.

Author Contributions: Yusuke Daiko performed experiments and wrote the paper; Yuki Oda performed experiments; Sawao Honda contributed TG-MS analysis; Yuji Iwamoto designed experiments.

Funding: This research was funded by New Energy and Industrial Technology Development Organization (NEDO) "The next-generation power electronics project for realizing a low-carbon society" project no. P10022.

Conflicts of Interest: The authors declare no conflict of interest.

\section{References}

1. Brown, J.F., Jr.; Vogt, L.H., Jr;; Katchman, A.; Eustance, J.W.; Kiser, K.M.; Krantz, K.W. Double chain polymers of phenylsisesquioxane. J. Am. Chem. Soc. 1960, 82, 6194-6195. [CrossRef]

2. Hah, H.J.; Kim, J.S.; Jeon, B.J.; Koo, S.M.; Lee, Y.E. Simple preparation of monodisperse hollow silica particles without using templates. Chem. Comm. 2003, 14, 1712-1713. [CrossRef]

3. Choi, J.Y.; Kim, C.H.; Kim, D.K. Formation and characterization of monodisperse, spherical organo-silica powders from organo-alkoxysilane-water system. J. Am. Ceram. Soc. 1998, 81, 1184-1188. [CrossRef]

4. Ma, C.; Kimura, Y. Preparation of nano-particles of poly(phenylsilsesquioxane)s by emulsion polycondensation of phenylsilanetriol formed in aqueous solution. Polym. J. 2002, 34, 709-713. [CrossRef]

5. Arkhireeva, A.; Hay, J.N. Synthesis of sub-200 nm silsesquioxane particles using a modified Stober sol-gel route. J. Mater. Chem. 2003, 13, 3122-3127. [CrossRef]

6. Bermundo, J.P.; Ishikawa, Y.; Yamazaki, H.; Nonaka, Y.; Uraoka, Y. Highly reliable polysilsesquioxane passivation layer for a-InGaZnO thin-film transistors. ESC J. Solid State Sci. Technol. 2014, 3, Q16-Q19. [CrossRef]

7. Bermundo, J.P.; Ishikawa, Y.; Fujii, M.N.; Nonaka, T.; Ishihara, R.; Ikenoue, H.; Uraoka, Y. Effect of excimer laser annealing on a-InGaZnO thin-film transistors passivated by solution-processed hybrid passivation layers. J. Phys. D Appl. Phys. 2016, 49, 035102. [CrossRef]

8. Li, G.Z.; Wang, L.; Toghiani, H.; Daulton, T.L.; Koyama, K.; Pittman, C.U. Viscoelastic and mechanical properties of epoxy/multifunctional polyhedral oligomeric silsesquioxane nanocomposites and epoxy/ladderlike polyphenylsilsesquioxane blends. Macromolecules 2001, 34, 8686-8693. [CrossRef]

9. Delvallé, C.; Meur, M.L.; Reeth, I.V. Personal care applications for phenylsilsesquioxane resins. IP.com J. 2016, $17,1-17$.

10. Shibata, S.; Yamane, M.; Kamada, K.; Ohta, K.; Sasaki, K.; Masuhara, H. Laser emission from dye-doped organic-inorganic particles of microcavity structure. J. Sol-Gel Sci. Technol. 1997, 8, 959-964. [CrossRef]

11. Biyachenko, A.N.; Yalymov, A.I.; Dronova, M.S.; Korlyukov, A.A.; Vologzhanina, A.V.; Eskova, M.A.; Jerome, L.; Larionova, J.; Guari, Y.; Forobatovskii, P.V.; et al. Family of polynuclear nickel cagelike phenylsilsesquioxanes; features of periodic networks and magnetic properties. Inorg. Chem. 2017, 56, 12751-12763. [CrossRef] [PubMed]

12. Biyachenko, A.N.; Dronova, M.S.; Yalymov, A.I.; Korlyukov, A.A.; Shul'pina, L.S.; Arkhipov, D.E.; Shubina, E.S.; Levisky, M.M.; Kirilin, A.D.; Shul'pin, G.B. Binclear cage-like copper(II) silsesquioxane ("cooling tower")-It's high catalytic activity in the oxidation of benzene and alcohols. Eur. J. Inorg. Chem. 2013, 30, 5240-5246. [CrossRef]

13. Wang, Z.; Li, Y.; Dong, X.-H.; Yu, X.; Guo, K.; Su, H.; Yue, K.; Wesdemiotis, C.; Cheng, S.Z.D; Zhang, W.-B. Giant gemini surafactants based on polystyrene-hydrophilic polyhedral oligomeric silsesquioxane shape amphiphiles: Sequential "click" chemistry and solution self-assembly. Chem. Sci. 2013, 4, 1345-1352. [CrossRef]

14. Takahashi, K.; Tadanaga, K.; Hayashi, A.; Tatsumisago, M. Substituent effects on the glass transition phenomena of polyorganosilsesquioxane particles prepared by two-step acid-base catalyzed sol-gel process. J. Ceram. Soc. Jpn. 2011, 119, 173-179. [CrossRef]

15. Takahashi, K.; Tadanaga, K.; Matsuda, A.; Hayashi, A.; Tatsumisago, M. Effects of phenyltriethoxysilane concentration in starting solutions on thermal properties of polyphenylsilsesquioxane particles prepared by a two-step acid-base catalyzed sol-gel process. J. Ceram. Soc. Jpn. 2007, 115, 131-135. [CrossRef] 
16. Daiko, Y.; Katagiri, K.; Shimoike, K.; Sakai, M.; Matsuda, A. Structures and electrical properties of core-shell composite electrolyte with multi-heterointerfaces. Solid State Ion. 2007, 178, 621-625. [CrossRef]

17. Daiko, Y.; Sakamoto, H.; Katagiri, K.; Muto, H.; Sakai, M.; Matsuda, A. Deposition of ultrathin Nation layers on sol-gel-derived phenylsilsesquioxane particles via layer-by-layer assembly. J. Electrochem. Soc. 2008, 155, B479-B482. [CrossRef]

18. Daiko, Y.; Sakakibara, S.; Sakamoto, H.; Katagiri, K.; Muto, H.; Sakai, M.; Matsuda, A. Formation of a high conductivity fuel cell electrolyte by pressing diphenylsiloxane-based inorganic-organic hybrid particles. J. Am. Ceram. Soc. 2009, 92, S185-S188. [CrossRef]

19. Kozuka, H. On ceramic thin film formation from gels: evolution of stress, cracks and radiative striations. J. Ceram. Soc. Jpn. 2003, 111, 624-632. [CrossRef]

20. Kozuka, H. Stress evolution on gel-to-ceramic thin film conversion. J. Sol-Gel Sci. Technol. 2006, 40, $287-297$. [CrossRef]

21. Kozuka, H.; Takenaka, S.; Tokita, H.; Okubayashi, M. PVP-assisted sol-gel deposition of single layer ferroelectric thin films over submicron or micron in thickness. J. Eur. Ceram. Soc. 2004, 24, 1585-1588. [CrossRef]

22. Katagiri, K.; Hasegawa, K.; Matsuda, A.; Tatsumisago, M.; Minami, T. Preparation of transparent thick films by electrophoretic sol-gel deposition using phenyltriethoxysilane-derived particles. J. Am. Ceram. Soc. 1998, 81, 2501-2503. [CrossRef]

23. Takahashi, K.; Tadanaga, K.; Matsuda, A.; Hayashi, A.; Tatsumisago, M. Formation of convex shaped poly(phenylsilsesquioxane) macropatterns on indium tin oxide substrates with hydrophobic-phydrophilic patterns using the electrophoretic sol-gel deposition method. J. Mater. Res. 2006, 21, 1255-1260. [CrossRef]

24. Shammas, N.Y.A. Present problems of power module packaging technology. Microelectron. Reliab. 2003, 43, 519-527. [CrossRef]

25. Fukuda, K.; Okamoto, D.; Okamoto, M.; Tadayoshi, D.; Mizushima, T.; Takenaka, K.; Fujisawa, H.; Harada, S.; Tanaka, Y.; Yonezawa, Y.; et al. Development of ultrahigh-voltage SiC devices. IEEE Trans. Electron Dev. 2015, 62, 396-404. [CrossRef]

26. Mimura, K.; Nakamura, Y.; Masaki, M.; Nishimura, T. Development of resin insulated material with high thermal conductivity and application to the power module. J. Photopolym. Sci. Technol. 2015, 28, 169-173. [CrossRef]

27. Edmond, J.A.; Das, K.; Davis, R.F. Electrical properties of ion-implanted p-n junction diodes in $\beta$-SiC. J. Appl. Phys. 1988, 63, 922-929. [CrossRef]

28. Chow, T.P.; Ramungui, N.; Ghezzo, M. Recent advances in high-voltage SiC power devices. High-Temp. Electron. Mater. Dev. Sens. Conf. 1998, 55-67.

29. Bai, J.G.; Yin, J.; Zhang, Z.; Lu, G.-Q.; van Wyk, J.D. High-temperature operation of SiC power devices by low-temperature sintered silver die-attachment. IEEE Trans. Adv. Pack. 2007, 30, 506-510. [CrossRef]

30. Palmour, J.W.; Edmond, J.A.; Kong, H.S.; Carter, C.H., Jr. 6H-silicon carbide devices and applications. Phys. B 1993, 185, 461-465. [CrossRef]

31. Dissado, L.A.; Sweeney, P.J.J. Physical mode for breakdown structures in solid dielectrics. Phys. Rev. B 1993, 48, 16261-16268. [CrossRef]

32. Illias, H.A.; Tunio, M.A.; Mokhlis, H.; Chen, G.; Bakar, A.H.A. Determination of partial discharge time lag in void using physical model approach. IEEE Tran. Dielectr. Electr. Insul. 2015, 22, 463-471. [CrossRef]

33. Mishra, D.; Satapathy, A. An experimental investigation on the effect of particle size on the thermal properties and void content of solid glass microsphere filled epoxy composites. Mater. Sci. Eng. 2016, 115, 012011. [CrossRef]

34. Varna, J.; Joffe, R.; Berglund, L.A.; Lundström, T.S. Effect of voids on failure mechanisms in RTM laminates. Comp. Sci. Technol. 1995, 53, 241-249. [CrossRef]

35. Chowdhury, K.A.; Talreja, R.; Benzerga, A.A. Effects of manufacturing-induced voids on local failure in polymer-based composites. J. Eng. Mater. Technol. 2008, 130, 021010. [CrossRef]

36. Ueda, T.; Helfen, L.; Morgeneyer, T.F. In situ laminography study of three-dimensional individual void shape evolution at crack initiation and comparison with Gurson-Tvergaard-Needleman-type simulations. Acta Mater. 2014, 78, 254-270. [CrossRef]

37. Adriaensens, P.; Pollaris, A.; Vanderzande, D.; Gelan, J. Critical analysis of network defects in cross-linked isobutylene-based elastomers by NMR imaging. Macromolecules 1992, 32, 4692-4699. [CrossRef] 
38. Findley, W.N.; Lai, J.S.; Onaran, K. Linear viscoelastic constitutive equations. In Creep and Relaxation of Nonlinear Viscoelastic Materials; Dover Publications: New York, NY, USA, 1976.

39. Mohanty, A.; Srivastava, V.K. Dielectric breakdown performance of alumina/epoxy resin nanocomposites under high voltage application. Mater. Des. 2013, 47,711-716. [CrossRef]

40. Boggs, S.A. Partial Discharge. III. Cavity-induced PD in solid dielectrics. IEEE Electr. Insul. Mag. 2002, 6, 11-16. [CrossRef]

(c)

(C) 2018 by the authors. Licensee MDPI, Basel, Switzerland. This article is an open access article distributed under the terms and conditions of the Creative Commons Attribution (CC BY) license (http://creativecommons.org/licenses/by/4.0/). 